\title{
ANALISIS PERMASALAHAN PEMBUATAN RENCANA PELAKSANAAN PEMBELAJARAN (RPP) TEMATIK KELAS IV DI SDS YKPP LIRIK
}

\author{
Dwi Rizkiana Putri ${ }^{1}$, Elpri Darta Putra ${ }^{1}$ \\ ${ }^{1}$ Universitas Islam Riau, Pekanbaru \\ *Corresponding Address: dwirizkiana035@gmail.com
}

Naskah diterima: 29Agustus 2021| Disetujui: 19 September 2021 | Diterbitkan: 22 September 2021

\begin{abstract}
This study aims to describe knowing the problems of making the fourth-grade thematic Learning Implementation Plan (RPP) at SDS YKPP Lyrics, Knowing how the teacher made the solutions to overcome the problems of making the fourth-grade thematic Learning Implementation Plan (RPP) at SDS YKPP Lyrics. This research uses a descriptive qualitative approach. The data sources of this study were two fourth-grade teachers and one principal. This research was conducted in the fourth grade of SDS YKPP Lyric, which is located on JL. Ukui No.1 Lyrics Area Lyrics District, Indragiri Hulu Regency. Data collection techniques in this study are; interviews, observations, and documentation. At the same time, the analysis of research data using the Miles \& Huberman model includes data reduction, presentation, and concluding. The problems of making Class IV thematic Learning Implementation Plans (RPP) at SDS YKPP Lyrics were limited time, lack of understanding of RPP components, difficulty determining learning strategies and learning media. The teacher's solution to making the thematic Learning Implementation Plan (RPP) for grade IV at SDS YKPP Lyric is to add additional information, attend training activities or workshops, and refer to the teacher's handbook, conduct discussions with colleagues.
\end{abstract}

Keywords: Learning Implementation Plan, thematic.

\begin{abstract}
Abstrak: Penelitian ini bertujuan untuk mendeskripsikan permasalahan pembuatan Rencana Pelaksanaan Pembelajaran (RPP) tematik dan mengetahui bagaimana solusi yang dilakukan guru untuk mengatasi permasalahan pembuatan Rencana Pelaksanaan Pembelajaran (RPP) tematik kelas IV di SDS YKPP Lirik. Penelitian ini menggunakan pendekatan deskriptif kualitatif. Sumber data penelitian adalah dua orang guru kelas IV dan satu kepala sekolah. Penelitian ini dilaksanakan di kelas IV SDS YKPP Lirik. Teknik pengumpulan data menggunakan wawancara, observasi, dan dokumentasi. Sedangkan analisis data penelitian menggunakan model Miles \& Huberman yang meliputi reduksi data, penyajian, dan penarikan kesimpulan. Hasil penelitian menunjukkan bahwa permasalahan pembuatan Rencana Pelaksanaan Pembelajaran (RPP) tematik kelas IV di SDS YKPP Lirik adalah keterbatasan waktu, kurang memahami komponen RPP, kesuliitan menentukan strategi pembelajaran dan media pembelajaran. Solusi yang dilakukan guru untuk mengatasi permasalahan pembuatan Rencana Pelaksanaan Pembelajaran (RPP) tematik kelas IV di SDS YKPP Lirik adalah menambah informassi tambahan, mengikutri kegiatan pelatihan, atau workshop, mengacu kepada buku pegangan guru, dan melakukan diskusi dengan rekan sejawat.
\end{abstract}

Kata kunci: Rencana Pelaksanaan Pembelajaran, tematik. 


\section{PENDAHULUAN}

UU No.20 th 2003 menyatakan bahwa pendidikan pada dasarnya merupakan sebuah rencana dalam mewujudkan suasana belajar di dalam proses pembelajaran agar peserta didik secara aktif mampu mengembangkan potensi dirinya untuk memperoleh kekuatan spritual keagamaan, pengendalian diri kepribadian, kecerdasan, akhlak mulia, serta keterampilan yang dapat diterima oleh dirinya, sekolah, masyarakat, bangsa, dan negara (Hasbullah, 2011).

Menurut Prastowo, Rencana Pelaksanaan Pembelajaran (RPP) merupakan sebuah taktik atau teknik yang disusun oleh guru untuk kebutuhan guru dalam melaksanakan tugas mengajar didalam kelas (Anugrahana, 2019). Tuntunan pada guru berkaitan dengan kemampuan guru dalam mengembangkan atau membuat Rancangan Pelaksanaan Pembelajaran (RPP) terlebih dahulu sebagai pedoman di setiap pertemuan pembelajaran di dalam kelas, tanpa adanya Rencana Pelaksanaan Pembelajaran (RPP) kegiatan pembelajaran tidak akan berjalan dengan baik dan lancar, dengan adanya Rencana Pelaksanaan Pembelajaran (RPP) pembelajaran lebih terarah dan tepat pada sasaran pembelajaran sesuai dengan tema, materi pelajaran, alokasi waktu serta menggunakan metode pembelajaran yang akan diajarkan kepada peserta didik sesuai karakteristik, sekolah, dan mata pelajaran (Prastowo, 2015).

Tematik merupakan bentuk model pembelajaran terpadu yaitu yang menekankan pada pola pengorganisasian materi yang terintegrasi dipadukan oleh suatu tema pembelajaran dan dibagi menjadi beberapa subtema lalu digabungkan dengan beberapa mata pelajaran yang akan diajarkan (Kurniawan, 2014). Pembelajaran tematik di sekolah dasar nampaknya belum berhasil mengatasi permasalahan dalam membuat prencanaan pembelajaran tematik yang dialami oleh guru, khususnya untuk permasalahan seperti kurang tepatnya guru dalam memilih media pembelajaran dan metode pembelajaran, sehingga pada siswa terjadi kurangnya pemahaman yang didapatkan dari pembelajaran yang diajarkan oleh guru (Bararah, 2017). Menurut Pannen, dalam merancang dan melakukan pembelajaran didalam kelas, jika guru mengaitkan dengan karakteristik siswa, maka hasil belajar siswa akan meningkat (Budiningsih, 2011).

Berdasarkan hasil wawancara yang dilakukan dengan guru kelas tinggi pada kelas IV di SDS YKPP Lirik pada tanggal 18 Januari 2021 selaku pendidik Refita Yuliana S. Pd. dan Hadiono S. Pd. yang bertanggung jawab penuh menyatakan terkendala oleh beberapa masalah sehingga belum sepenuhnya sesuai dengan yang diharapkan di mana guru mengalami kesulitan dalam pembuatan perencanaan pembelajaran, dan guru pun belum memiliki kesiapan kemampuan dalam melaksanakan pembelajaran di kelas tinggi. Salah satu penyebab dari permasalahan tersebut, yaitu guru mengalami kesulitan ketika menentukan sebuah metode pembelajaran dan media pembelajaran karena harus 
menyesuaikan dengan karakteristik setiap siswa di dalam pembelajaran di kelas, guru cenderung menggunakan metode pembelajaran secara berulang-ulang diantaranya metode ceramah, metode diskusi, dan metode latihan (dril). Selain itu guru juga terkendala dalam membuat media pembelajaran karena dalam satu kali pertemuan guru harus menyiapkan beberapa media pembelajaran, sehingga berasarkan hal di atas menyebabkan siswa cenderung memiliki respon yang tidak baik, bosan, mengantuk, asik dengan dunia sendiri dan bermain dengan teman sebangkunya. Hal di atas jika diperhatikan guru masih mengalami kesulitan dalam pembuatan Rencana Pelaksanaan Pembelajaran (RPP) masih terkesan sangat rendah (Aditya, 2016).

\section{METODE}

Jenis penelitian yang digunakan adalah penelitian deskriptif kualitatif. Penelitian ini dilaksanakan di kelas IV SDS YKPP Lirik yang berada di Jl. Ukui No.1 Lirik Area Kecamatan Lirik Kabupaten Indragiri Hulu. Penelitian ini bertujuan untuk memberikan gambaran secara garis besar tentang analisis permasalahan pembuatan Rencana Pelaksanaan Pembelajaran (RPP) tematik kelas IV di SDS YKPP Lirik. Dalam penelitian ini akan menggunakan tiga teknik pengumpulan data, yaitu menggunakan teknik pengumpulan data melalui wawancara untuk mengumpulkan dan memperoleh data dari guru kelas IV terkait dengan bagaimana permasalahan pembuatan Rencana Pelaksanaan Pembelajaran (RPP) tematik kelas IV di SDS YKPP Lirik (Satori \& Komaria, 2014). Observasi dilakukan kepada bagian inventaris dan guru kelas tinggi, untuk memperoleh data tentang bagaimana permasalan Pembuatan Rencanaan Pelaksanaan Pembelajaran (RPP) kelas IV di SDS YKPP Lirik (Yusuf, 2014). Dokumentasi digunakan untuk membantu peneliti dalam mengumpulkan data mengenai telaah dokumen-dokumen yang peneliti butuhkan.

Instrumen dalam penelitian ini berupa pedoman wawancara (kepala sekolah dan guru). Penelitian dilaksanakan secara betahap, penelitian merencanakan penelitian pada bulan agustus 2021. Analisis data didalam penelitian ini digunakan untuk mengolah data dan memeriksa data infomasi dimulai peneliti masuk ke lapangan dan selama dilapangan sampai dengan selesai dilapangan yang meliputi reduksi data, penyajian data, dan menarik kesimpulan. Teknik yang digunakan dalam penelitian Model Miles \& Hubermen (Hardani, 2020).

\section{HASIL DAN PEMBAHASAN}

Rencana Pelaksanaan Pembelajaran (RPP) merupakan bagian terpenting bagi guru atau kewajiban bagi guru didalam satuan pendidikan yang digunakan sebagai acuan atau pedoman guru dalam melaksanakan tugasnya sebagai pendidik yang sesuai dengan kebutuhan siswa agar 
pembelajaran yang diterapkan lebih terarah sehingga tercapai tujuan pembelajaran yang diinginkan. Tanpa adanya Rencana Pelaksanaan Pembelajaran (RPP) tujuan pembelajaran tidak akan terlaksana secara maksimal dan matang.

Tujuan Rencaan Pelaksanaan Pembelajaran (RPP) yaitu untuk kepentingan guru sendiri agar tujuan pembelajaran yang dibuat oleh guru dapat berjalan dengan baik dan tercapai tujuan belajar. Tujuan adanya pembuatan Rencana Pelaksanaan Pembelajaran (RPP) ini untuk memenuhi tuntunan permintaan kepala sekolah yang akan di supervisi, dengan adanya tujuan ini guru dapat menjamin pelaksanaan pembelajaran dapat berjalan dengan baik asal sesuai dengan komponen-komponen Rencana Pelaksanaan Pembelajaran seperti dalam pemilihan metode dan media pembelajaran.

Komponen-komponen Rencana Pelaksanaan Pembelajaran (RPP) merupakan susunan langkah-langkah pembelajaran atau identitas Rencana Pelaksanaan Pembelajaran (RPP) yang dikembangkan sesuai dengan kompetensi dasar berdasarkan subtema yang dilaksanakan satu kali pertemuan atau lebih agar kegiatan pembelajaran tersusun dan terperinci dengan baik dan jelas. Pada dasarnya komponen-komponen Rencana Pelaksanaan Pembelajaran (RPP) sama dengan RPP pada umumnya hanya saja Rencana Pelaksanaan Pembelajaran (RPP) ini lebih menekankan atau menonjol pada rumusan komponen-komponen dengan pengalaman belajar dengan tema yang telah di tetapkan. Peran kepala sekolah dalam penyusunan RPP guru, yaitu sebagai pembina yang bertugas membina dan memberi contoh dalam penyusunan RPP guru, serta sebagai supervisi yang bertugas memberi arahan dan masukan dalam penyusunan RPP guru.

\section{Komponen dalam Rencana Pelaksanaan Pembelajaran (RPP) Tematik}

Berdasarkan data yang diperoleh, berupa RPP Guru kelas IV di SDS YKPP Lirik, peneliti melakukan penelitian dengan langsung observasi ke tempat penelitian dan melakukan wawancara kepada informan penelitian. Adapun hasil penelitian yang didapat oleh peneliti adalah sebagai berikut:

a. Identitas RPP Hasil penelitian yaitu identitas RPP telah sesuai dengan ketentuan kurikulum, tetapi untuk identitas mata pelajaran belum semua RPP sesuai dengan ketentuan rumusan identitas mata pelajaran. Terdapat satu RPP yang tidak mencantumkan nama sekolah pada rumusan identitas

b. Tujuan pembelajaran hasil penelitian yaitu semua RPP telah sesuai dengan ketentuan. Rumusan tujuan pembelajaran RPP sesuai dengan rumusan indikator dan komptensi dasar yang terdapat pada silabus. 
c. Materi pembelajaran hasil penelitian rumusan materi pembelajaran RPP belum semua RPP sesuai dengan ketentuan. Rumusan materi pada RPP guru 2 telah sesuai dengan kompetensi dasar dan tujuan pembelajaran, sedangkan guru 1 rumusan materi tidak sesuai dengan kompetensi dasar dan tujuan pembelajara. Guru 2 mencantumkan materi pembelajaran dan melengkapi uraiannya yang telah dikembangkan pada silabus, sedangkan guru 1 tidak mencantumkan pokok materi pada materi pembelajaran RPP

d. Metode pembelajaran hasil peneltian metode pembelajaran semua RPP sudah sesuai ketentuan. Semua rumusan metode pembelajaran telah disesuaikan dengan situasi dan kondisi pesereta didik. Krsteristik dari setiap indikator telah disesuaikan dengan kompetensi yang hendak dicapai pada setiap mata pelajaran.

e. Kegiatan pembelajaran hasil penelitihan kegitan pembelajaran semua RPP sesuai dengan ketentuan. Kegiatan pembelajaran mencakup kegiatan pendahuluan, kegiatan inti, kegiatan penutup. Kegiatan pembelajaran semua RPP sudah sesuai ketentuan.

f. Media pembelajaran hasil penelitian semua RPP tidak sesuai dengan komponen media pembelajaran yang digunakan dipilih dengan cermat, sehingga digunakan dengan tepat dan media pembelajaran tidak disesuaikan dengan silabus.

g. Sumber belajar hasil penelitihan rumusan sumber belajar semua RPP yang tidak sesuai dengan ketentuan, RPP setiap guru tidak menuliskan sumber belajar.

h. Penilaian hasil penelitian semua RPP tidak sesuai dengan ketentuan. Rumusan penilaian tidak disesuaikan dengan indikator pencapaian kompetensi dan mengaju kepada penilaian (Daryanto, 2010).

\section{Kendala Pembuatan Rencana Pelaksanaan Pembelajaran (RPP) Tematik}

Berdasrkan hasil wawancara kendala yang di hadapi oleh masing-masing guru berbeda-beda. Guru 1 menyatakan bahwa kendala dalam pemyusunan RPP adalah pada saat menentukana strategi pembelajaran yang sesuai dengan kemampuan siswa. Guru 1 mengalami kendala dalam pengaturan waktu penyusunan RPP, menyatakan kadang susah membagi waktu, setiap guru juga memiliki kegiatan yang banyak pada saat di luar pelajaran. Setiap guru memiliki banyak kesibukan seperti urusan rumah tangga (Deta, 2017).

Guru 1 dan 2 mengalami kendala berbeda-beda. Guru 1 kurang paham pada komponen media pembelajaran, materi pembelajaran, sumber pembelajaran, dan penialain. Guru1 beralasan untuk komponen materi pembelajaran kesulitan untuk menyesuaikan dengan tujuan pembelajaran dan kompetensi dasar, sulit menguraikan materi pembelajaran, dan melengkapi uraian-uraian yang akan 
dikembangkan karena kesulitan menentukan sumber pembelajaran. Guru 1 memiliki keterbatasan sumber belajar yang akan digunakan karena kurangnya mencari informasi atau pengetahuana tambahan dari internet (Gunawan, 2014).

Guru 2 kurang memahami komponen identidas RPP dan sumber belajar, guru 2 beralasan memiliki keterbatasan dalam mengopersikan komputer. Guru 2 juga mengalami kesulitan saat menentukan strategi pembelajaran yang sesuai dengan semua kemampuan siswa. Guru juga mengalami kendala dalam menentukan media pembelajaran yang sesuai dengan krasteristik siswa. Guru juga menalami kendala dalam menyusun penilaian yaitu permasalahan dalam penyusunan bentuk soal evaluasi dan bervariasi (Hadi, 2017).

Kendala pada saat penyusunan RPP adalah waktu sangat sulit dalam membagi waktu. Sehingga guru tidak mampu menyusun perangkat pembelajaran secara optimal. Pendidik banyak memiliki kesibukan seperti kesibukan urusan rumah tangga. Guru kurang dalam mencari informasi atau pengtahuan tambahan dari internet kemajuan teknologi ketentuannya juga memiliki dampak dibidang pendidikan. Hal ini juga harus dapat dimanfaatkan oleh guru sebagai sarana untuk menambah wawasan dan pegetahuan dengan memanfaatkan teknologi.

Guru kurang memahami komponen komponen yang terdapat pada RPP seperti kesulitan dalam menentukan media pembelajaran yang sesuai dengan krasteristik anak. Memahami setiap krakter siswa sangat diperlukan bagi seorang guru, supaya RPP yang akan dirancang dapat mengakomodasi seluru siswa, sehingga siswa dapat belajar dengan optimal.

Dalam penyusunan penialaian tentunya setiap guru mempersiapkan instrumen penilaian, seperti menyususun butir soal yang akan diberikan kepada siswa dan kriteria penialainnya. Terkait dengan hal tersebut, tidak semua guru dapat menyusun penilaian dengan baik. Guru mengalami kendala dalam melakukan analisis soal dengan berbagai kriteria, seperti kriteria sulit, tidak sulit, dan sedang. Guru menyusun penilaian belum sampai pada tahap melakukan analisisi soal setiap item nya. Guru juga setelah melakukan penilaian jarang melakukan analis isi, seperti menganalisis hasil belajar siswa dengan melihat berapa banyak peserta didik yang tuntas dan melakukan analisis soal sangat sulit. Guru juga mengalami permasalahan dalam penyusunan bentuk soal evaluasi bervariasi, dalam menyususn butir soal terdapat guru jarang menyusun soal dalam bentuk pilihan ganda, biasanya hanya menysusun soal dengan bentuk isian singkat dan uraian.

\section{Solusi Kendala Pembuatan RPP Tematik}

Berdasarkan hasil wawancara dan observasi bersama guru kelas IV dan kepala sekolah di SDS YKPP lirik ada beberapa upaya-upaya yang dilakukan setiap guru dalam mengatasi kendala dalam 
pembuatan RPP adalah memanfaatkan waktu yang ada untuk membuat RPP beberapa ekslamper (Heriyanto, 2013). Guru mencari acuan dalam pembuatan RPP seperti buku pegangan dan mencari informasi tambahan dari internet. Guru juga bisa melakukan diskusi dengan teman sejawat atau dengan mengikuti KKG (Kerja Kelompok Guru), mempertimbangkan kemampuan, kecerdasan, dan pengetahuan yang dimiliki siswa. Pada saat pembelajaran, guru meningkatkan perhatian khusus kepada siswa yang mempunyai kemampuan kurang (Herviani, 2016).

Berdasarkan kendala yang dihadapi setiap guru, perlu adanya upaya untuk meyelesaiakan kendala tersebut. Hal yang dapat dilakukan guru untuk mengatasi permasalahan pembuatan Rencana Pelaksanaan Pembelajaran (RPP) adalah dengan cara guru terlebih dahulu menyusunan langkahlangkah metode pembelajaran dan juga media pembelajaran sesuai dengan kebutuhan siswa (Anugrahana, 2013). Sebaiknya guru perlu memperhatikan terlebih dahulu pemilihan media, diantaranya (1) menyesuaiakan kebutuhan siswa, (2) menyesuaikan dengan tujuan pembelajaran, (3) menyesuaikan dengan materi pembelajaran, dan (4) menyesuaikan dengan metode pembelajaran (Hadi, 2017). Keempat poin tersebut harus menjadi dasar pemilihan sebuah media pembelajaran, karena media akan berperan optimal sebagai pengantar informasi. Media tersebut merupakan media yang disenangi siswa dengan tujuan pembelajaran sesuai dengan materinya.

Upaya lain yang dapat dilakukan dalam mengatasi kendala tersebut bahwa guru memanfaatkan waktu yang ada untuk membuat RPP beberapa ekslamper. Upaya lain dengan mencari informasi atau pengetahuan tambahan dalam mengakses jaringan internet. Perkembangan teknologi harus dimanfaatkan oleh seorang guru sebagai fsiolitass dalam menambah wawasan dan pengetahuan guru untuk selalu belajar. Guru juga dapat melakukan pembuatan organisasi keguruan seperti KKG (Kelompok Kerja Guru) sebagai wadah bagi para guru untuk saling bertukar pikiran dan diskusi.

Upaya yang dilakukan guru dengan berusaha untuk selalu belajar, dalam hal ini guru yang mengalami kesulitan menyusun penilaian dapat belajar dengan membaca buku tentang penilaian berupa buku pegangan guru yang sudah tersedia. Pendidik yang berkualitas akan selalu menyusun perencanaan untuk proses pembelajarannya, sehingga tidak ada alasan guru ketika mengajar di kelas tanpa rencana pembelajaran. Guru perlu menyadari menyampaikan perangkat pembelajaran yang disusun tentunya sangat berguna dalam menunjang proses pembelajaran yang disusun tentunya sangat berguna dalam menunjang proses pembelajaran. Adanya perangkat dalam kegiatan pembelajaran dapat dirancang secara sistematis dan memudahkan guru dalam melaksanakan pembelajaran.

Upaya yang dilakukan guru untuk menentukan strategi belajar anak, yaitu saat menentukan strategi pembelajaran yang sesuai dengan karakteristik siswa yang berbeda-beda. Kendala tersebut 
dapat diatasi dengan meningkatkan perhatian khusus kepada anak yang mempunyai kemampuan yang kurang.

Hasil penelitihan ini sejalan dengan teoritis menurut (Anugrahana, 2019) bahwa ada beberapa upaya mengatasi permasalahan pembuatan Rencana Pelaksanaan Pembelajaran (RPP) dalam menentukan metode yang dapat dilakukan sebagai berikut:

a. Disiplin dalam mengajar, sehingga proses pembelajaran dapat memberikan dampak positif bagi guru dan siswa.

b. Selalu melakukan perbaikan diri atas kekurangan dalam merancang dan melaksanakan proses pembelajaran, seperti menyesuaikan metode pembelajaran secara tepat. Ketika memasuki tahun ajaran baru, sedapat mungkin sudah mempersiapkan hari efektif dan agenda terjadwal yang akan dilakukan selama satu tahun ke depan, agar tahu hari efektif yang akan digunakan. Persiapan yang bisa dilakukan oleh guru adalah membuat indikator yang sesuai dengan tema, subtema, dan pembelajaran yang akan dilakukan, mencari referensi berbagai macam pendekatan, model, metode, dan teknik/tipe pembelajaran, kemudian menerapkannya dalam pembelajaran, memahami materi yang akan diajarkan terlebih dahulu baru mengembangkan RPP berdasarkan pemetaan $\mathrm{KD}$, memahami deskripsi kegiatan terlebih dahulu, dan menyimpulkan berdasarkan materi.

c. Berdiskusi dengan teman sejawat atau teman pararel dalam mengajar. Hal ini jika dilakukan akan sangat membantu guru dalam mengajar. Saling berbagi pengalaman dalam menyusun Rencana Pelaksanaan Pembelajaran (RPP).

d. Selalu update informasi, selalu mengikuti perkembangan dari pendidikan supaya tidak ketinggalan. Hal ini dilakukan agar guru tidak tertutup dan melek informasi. Permasalahan yang pertama adalah berkaitan dengan metode, maka yang akan guru lakukan adalah mencari informasi tambahan, menentukan sintaks, dan memilih metode.

e. Mencari informasi tambahan. Bentuk usaha yng berkaitan dengan informasi yaitu banyak membaca buku dan mengakses info tentang berbagai macam metode pembelajaran, bertanya kepada ahli tentang teknik yang sesuai untuk digunakan.

f. Menentukan sintaks atau sering disebut dengan langkah-langkah. Sintaks disesuaikan dengan metode ataupun model yang dipilih oleh guru. Maka guru harus mencari referensi yang dapat membantu guru dalam menentukan sintaks. Referensi itu bisa diperoleh dari buku-buku ataupun dari internet. 
g. Memilih metode. Memahami indikator yang akan dicapai kemudian menentukan metode yang sesuai. Mencari informasi dengan membaca buku yang berkaitan dengan model-model pembelajaran, kemudian menerapkan model-model tersebut dalam RPP yang dibuat

\section{KESIMPULAN}

Analisis permasalahan pembuatan Rencana Pelaksanaan Pembelajaran (RPP) tematik kelas IV SDS YKPP Lirik pada penelitian ini dilihat dari pembuatan Rencana Pelaksanaan Pembelajaran (RPP) dan pelaksanaan di dalam kelas. Data penelitian didapatkan melalui wawancara, observasi, dan dokumentasi. Berdasarkan pembahasan, dapat disampaikan simpulan bahwa permasalahan pembuatan Rencana Pelaksanaan Pembelajaran (RPP) tematik kelas IV di SDS YKPP Lirik adalah keterbatasan waktu, kurang memahami komponen RPP, kesuliitan menentukan strategi pembelajaran, dan media pembelajaran. Solusi yang dilakukan guru untuk mengatasi permasalahan pembuatan Rencana Pelaksanaan Pembelajaran (RPP) tematik kelas IV di SDS YKPP Lirik adalah menambah informassi tambahan, mengacu kepada buku pegangan guru, dan melakukan diskusi dengan rekan sejawat.

\section{DAFTAR PUSTAKA}

Aditya, Y, D. (2016). Pengaruh Penerapan Metode Pembelajaran Resitasi Terhadap Hasil belajar Matematika Siswa. Jurnal SAP, 1(2).

Anugrahana, A. (2019). Hambatan Guru SD Dalam Penyusunan SPP (Subject Specific Pedagogy) Kurikuylum Baru Di Sekolah Dasar. ejournal.uksw.edu, 35 (2).

Bararah, I. (2017). Efektifitas Perencanaan Pembelajaran Dalam Pembelajaran Pendidikan Agama Islam Di Sekolah. Jurnal Mudarrisuna. 7(1).

Budiningsih, A, C. (2011). Karakteristik Siswa Sebagai Pijakan Dalam Penelitian Dan Metode Pembelajaran. Jurnal Cakrawala Pendidikan. 1(1).

Daryanto. (2010). Media Pembelajaran Peranannya Sangat Penting Dalam Mencapai Tujuan Pembelajaran. Yogyakarta. Gava Media.

Deta, A, U. (2017). Peningkatan Pemahaman Materi Kuantisasi Besaran FisisPada Calon Guru Fisika Menggunakan Metode Diskusi Kelas Dan Scaffolding. Jurnal Ilmiah Pendidikan Fisika Al-Biruni 6(2).

Gunawan, Imam. (2014). Metode Penelitian Kualitatif : Teori Dan Peraktik. Jakarta: Bumi Aksara. 
Hadi, S. (2017). Efektivitas Penggunaan Video Sebagai Media Pembelajaran Untuk Siswa Sekolah Dasar. Jurnal Transformasi Pendidikan. 1(15).

Hardani, dkk. (2020). Metode Penelitian Kualitatif Dan Kuantitatif. Yogyakarta: CV Pustaka Ilmu Group Yogyakarta.

Hasbullah. (2011). Dasar-Dasar Ilmu Pendidikan. Jakarta: PT Raja Grafindo Persada.

Heriyanto., Prabowo, A. (2013). Analisis Pemanfaatan Buku Elektronik (E-Book) Oleh Pemustaka Di Perpustakaan SMA Negri 1 Semarang. Jurnal Ilmu Perpustakaan. 2(2).

Herviani, V., Febriansyah, A. (2016). Tinjauan Atas Penyusunan Laporan Keuangan Pada Young Enterpreneur Academy Indonesia Bandung. Jurnal Riset Akutansi. 8(2).

Hidayah, N. (2015). Pembelajaran Tematik Integratif Di Sekolah Dasar. Jurnal Pendidikan dan Pembelajaran Dasar. 2(1).

Istarani. (2012). Kumpulan 39 Metode Pembelajaran. Medan: CV ISCOM MEDAN.

Kurniawan, Deni. (2014). Pembelajaran Tematik Terpadu. Bandung: ALFABETA.

Kustandi, Cecep. Sutjipto, Bambang. (2011). Media Pembelajaran Manual Dan digital. Bogor: Gahlia Indonesia.

Maesaroh, S. (2013). Peranan Metode Pembelajaran Terhadap Minat Dan Prestasi Belajar Pendidikan Agama Islam. Jurnal Kependidikan. 1(1).

Majid, Abdul. (2014). Pembelajaran Tematik Terpadu. Bandung: PT REMAJA ROSDAKARYA.

Miftah, M. (2013). Fungsi Dan Peran Media Pembelajaran Sebagai Upaya Peningkatan Kemampuan Belajara Siswa. Jurnal KWANGSAN. 1(2).

Muklis, M. (2014). Pembelajaran Tematik. Jurnal Fenomena. 4(1).

Nasution, A, R. (2019). Impelementasi Pembelajaran Tematik Dengan Tema Diri Sendiri Di TK A PAUD Khairin Kids Medan Tembung. Jurnal Raudhah.07(1).

Nazliah, R., Harahap, D, R. (2019). Analisis Rencana Pelaksanaan Pembelajaran (RPP) Biologi Kurikulum 2013 Kelas X Semester 1 Tahun Ajaran 2016/2017 Di MAS Islamiyah Gunting Saga Kualuh Selatan Kabupaten Labuhanbatu Utara. Jurnal Biolokus. 2(2).

Nugrahani, Farida. (2014). Metode Penelitian Kualitatif dalam pendidikan. Surakarta: Pilar Media.

Nurmaya, N., Perangin, N, D. (2017). Pengaruh Penerapan Metode Pembelajaran Latihaan/Drill Terhadap Hasil Belajar Pelajaran Keterampilan Siswa Kelas VII SMP NEGERI 9 Medan. Jurnal Pendidikan Tata Busana. 1(1). 
Pauziah, R. (2017). Penerapan Metode Diskusi Untuk Meningkatkan Aktivitas Siswa Pada Pembelajaran Menirukan Pembacaan Pantun Anak Di Kelas IV SD Negeri 19 Kepahiang Kabupaten Kepahiang Provinsi Bengkulu. Jurnal Ilmiah Pendidikan Guru Sekolah Dasar. $10(1)$.

Prastowo, Andi. (2015). Menyusun Rencana Pelaksanaan Pembelajaran Tematik Terpadu. Jakarta: PRENADAMEDIA GROUP.

Pratiwi, I, N. (2017). Penggunaan Media Video Call Dalam Teknologi Komunikasi. Jurnal Ilmiah Dinamika Sosial. 1(2).

Putri, D, S. Citra E, D. (2019). Problematika Guru Dalam Menggunakan Media Pembelajaran Pada Mata Pelajaran Ips Di Madrasah Ibtidaiyah Darussalam Kota Bengkulu. Indonesian Journal of Social Science Education Volume 1, Nomor 1, Januari 2019. 1 (1).

Rintayanti, P., Yamtinah, S., Yusrina, H. (2018). Implementation Of Thematic Learning On Curriculum 2013 In 4th Grade Elementary School. International Journal Of Pedagogy And Teacher Education (IJPTTE). 2(2).

Satori, Djam'an \& Komaria Aan. (2014) Metodologi Penelitian Kualitatif. Bandung. ALFABETA.

Siskandar., Nugroho., Abduh, M. Evaluasi Pembelajaran Tematik Di lihat Dari Hasil Belajar Siswa. Indonesian Journal Of Curriculum And Educational Technology Studies. 1(1).

Susetya, B. (2017). Meningkatkan Kemampuan Guru Dalam Menyusun Silabus Dan RPP Melalui Supervisi Akademi DI SD N Gambiran Yogyakarta Tahun 2016. Jurnal Taman Cendekia.1(2).

Tabany, Al, Badar, Trianto. (2011). Desain Pengembangan Pembelajaran Tematik Bagi Anak Usia Dini TK/RA \& Anak Kelas Awal SD/MI Impelementasi Kurikulum 2013. Jakarta: PERNADAMEDIA GROUP.

Wedi, A. (2016). Konsep Dan Masalah Penerapan Metode Pembelajaran : Upaya Peningkatan Mutu Pembelajaran Melalui Konsistensi Teoretis-Praktis Penggunaan Metode Pembelajaran. Jurnal Edcomtech. 1(1).

Widyaningrum, R. (2012). Model Pembelajaran Tematik Di MI/SD. Jurnal Kependidikan Dan Kemasyarakatan. 10(1).

Yusuf, Muri. (2014). Metode Penelitian Kuantitatif, Kualitatif, \& Penelitian Gabungan. Jakarta: PERNADAMEDIA GROUP.

Zubaidah, E. (2015). Pemanfaatan Media Pembelajaran Untuk Menciptakan Lingkungan Kelas SD (Alternatif Penciptaan Laboratorium SD Yang Efektif). Jurnal Prima Edukasia. 3 (1). 
ANALISIS PERMASALAHAN PEMBUATAN RENCANA PELAKSANAAN PEMBELAJARAN (RPP) ...

Dwi Rizkiana Putri, Elpri Darta Putra 